Jpn. J. Limnol., 60 : 281-289, 1999

\title{
Annual and Seasonal Variations in Net Production, Biomass and Life Span of Floating Leaves in Brasenia schreberi J. F. GMEL.
}

\author{
Hidenobu KUNII
}

\begin{abstract}
Quantitative observations on the seasonal changes in leaf life span, leaf area and leaf mass of a floating-leaved aquatic macrophyte, Brasenia schreberi J. F. Gmel., were carried out from 1986 to 1988 in an irrigation pond in Matsue, Shimane Prefecture, Japan, using a non-destructive leaf-marking method. During those three years, the seasonal maximum leaf area index, seasonal maximum leaf mass, and annual net production changed considerably ; 0.90-1.36, 52.5-80.5 g dry weight $\mathrm{m}^{-2}$ and $154.9-243.5 \mathrm{~g}$ dry weight $\mathrm{m}^{-2} \mathrm{yr}^{-1}$, respectively. In contrast, the annual mean life span, turnover of leaves in number, and the annual net production to seasonal maximum biomass ratio $(\mathrm{P} /$ $\mathrm{B}_{\max }$ ratio) were relatively constant around the values of 25-28 d, 6 . 0-6.3 and 2.95-3.25 $\mathrm{yr}^{-1}$, respectively. While the net production $(P<0.05)$ and leaf mass $(P<0.005)$ of leaves had a significant linear relation to cumulative sunshine duration from 1 May to late September, there was no significant correlation between cumulative temperature and annual net production and leaf mass. Present result suggests that sunshine duration during the growing season is crucial for the leaf production of $B$. schreberi.
\end{abstract}

Key words : aquatic plant, irrigation pond, sunshine duration, water shield.

\section{INTRODUCTION}

The important function of aquatic macrophytes, especially that of floatingleaved plants in shallow water, has been described (den HARTOG and van der VELDE, 1988) and many data have been accumulated on the life span and production of floating-leaved plants. Most of these, however, were obtained in a single year of observation, and only a few describe year-to-year changes (TsuchiYa et al., 1987). It is known that there is a considerable year-toyear variation in the seasonal pattern of the biomass of floating-leaved plants (e.g., van der Velde and PeElen-Bexkens, 1983 ; Tsuchiya et al., 1987). Therefore, it is necessary to monitor the annual changes in biomass and production for several years in order to estimate these parameters precisely under field conditions.

In this paper, results of a three-year observation of the production and 
turnover of lamina in floating leaves of Brasenia schreberi J. F. GMEL. is presented. This plant is an edible floating-leaved aquatic plant, and several studies have been done in Japan on its distribution and growth characteristics (TozAKI, 1982, 1984, 1985 ; MATsuda and HARA, 1985 ; Hara et al., 1988). Additional studies have been done on its geographical distribution (RAymond and Dansereau, 1953), winter bud production (Chrysler, 1938 ; ADAMS, 1969), morphology and systematics (KHANNA, 1965 ; KAUL, 1976 ; ITo, $1986 ; 1987$ ), phytotoxicity (Elakovich and Wooten, 1987), chemical composition (Hutchinson, 1975) and rhizome longevity (KunII, 1993). In addition, KUNII and ARAMAKI (1987) published a limited account of the behavior of floating leaves in $B$. schreberi. However, since there is no detailed information on the annual changes in biomass production of this plant, the author conducted the present study from 1986 to 1988 .

\section{SITE AND METHODS}

\section{Site description}

This study was done in a small and shallow irrigation pond named Engi-ike, Matsue, Shimane Prefecture, Japan $\left(132^{\circ} 56^{\prime} \mathrm{E}, 35^{\circ} 28^{\prime} \mathrm{N}\right)$. This pond is habitat to seven emergent, four floating-leaved, six submerged, and
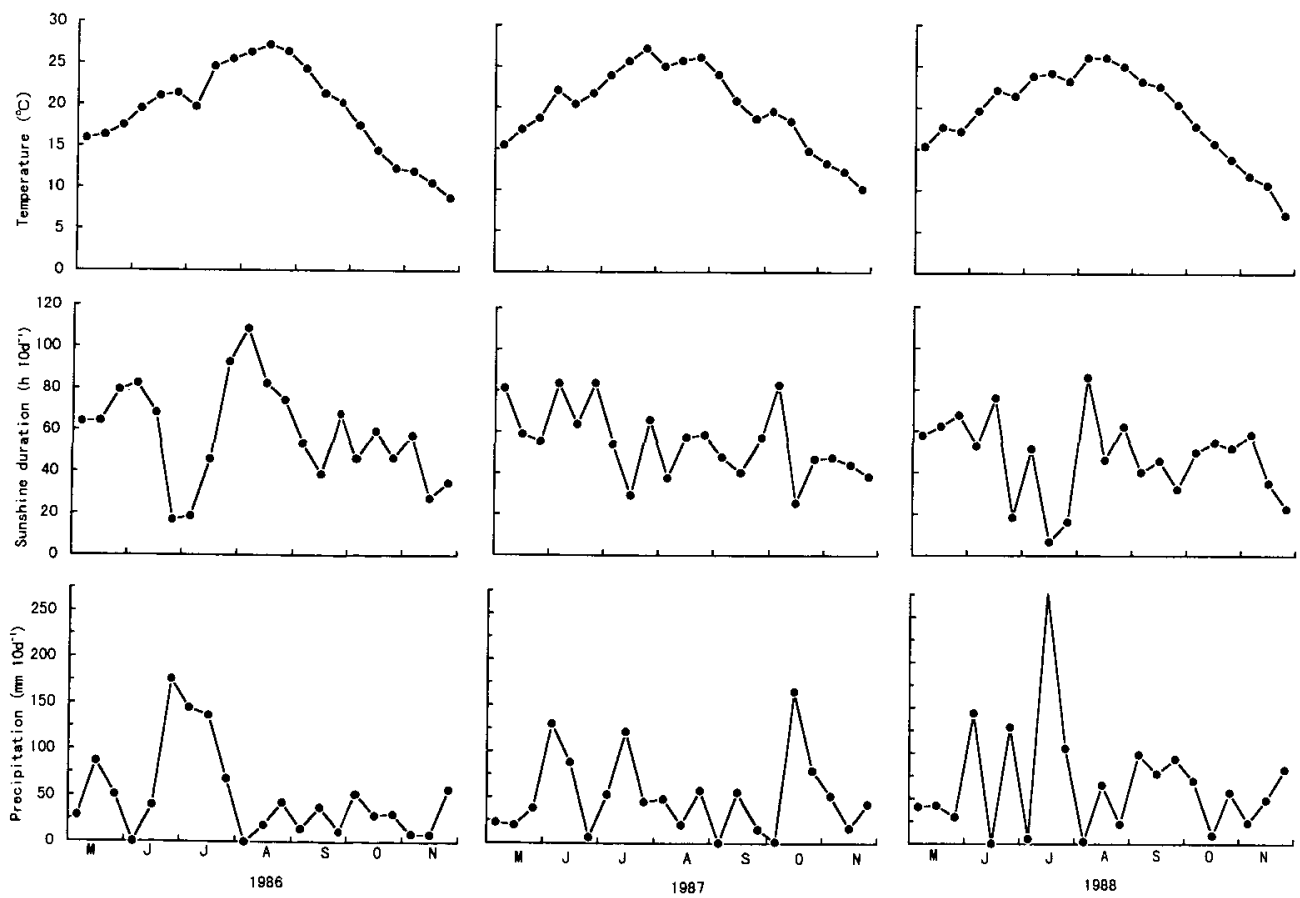

Fig. 1 Temporal changes in mean air temperature, sunshine duration and precipitation in 1986, 1987 and 1988 observed in Matsue, Shimane Prefecture. Data are obtained from the monthly reports of the Matsue Meteorological Observatory, and the values averaged at 10 -day intervals are plotted in the figure. 
four free-floating aquatic plants. Of the four floating-leaved aquatic plants observed (B. schreberi, Nymphaea tetragona GEORGI, Trapa sp. and Nymphoides indica (LinN.) O. KunTze.) , B. schreberi grows dominantly along the fringe of the north-eastern part of the pond. Seasonal changes in temperature, sunshine duration and precipitation from 1986 to 1988 are shown in Figure 1. For a detailed description of the pond, see KunII and TsubaKI (1987).

\section{Determination of leaf size and dry weight}

A total of 233 complete floating leaves were collected from the pond to determine the relationship between leaf size and dry weight. Leaf length and width were measured by a ruler, and leaf surface area was measured by a Graphtech KD 3838 digitizer. All materials were oven-dried at $80^{\circ} \mathrm{C}$ for $48 \mathrm{hr}$ and weighed.

\section{Determination of leaf development and life span}

To detect the fate of each individual leaf, field observations were made throughout the growing seasons of three successive years from 1986 to 1988, using two $50 \times 50 \mathrm{~cm}$ wooden frame permanent quadrates settled on the water surface where the plant existed in a dense pure stand. Since one quadrat was severely invaded by Nymphoides indica, the results in this paper are shown only for the other quadrat. Newly developed leaves at the water surface were marked by tying numbered vinyl tapes around the petiole at about one week intervals. Length and width of each floating leaf were measured, and visual observation of missing or damaged areas was done at each date to evaluate the potential and actual leaf areas. Here the actual area means the potential area minus the lost area. Leaf life span is defined as the period from the first appearance of leaf-blades on the water surface to their complete decay or disappearance.

\section{RESULTS AND DISCUSSION}

Figure 2 shows the temporal changes in the leaf birth (appearance)/death (disappearance) rate and leaf life span from 1986 to 1988. Although there were marked fluctuations, seasonal patterns in both leaf birth / death rate and life span were almost similar throughout the years. New leaf appearance at the water surface occurred from late May until late October, and there appear to be two peaks in leaf birth rate within a year; one around May-June and another around August-September. The leaf birth rate in 1988 was lower than those in 1986 and 1987, and the cumulative number of leaves produced during the vegetation period was 277, 247 and 159 in 1986, 1987 and 1988, respectively. The leaf life span gradually increased and reached its peak in September (Fig. 2). The annual mean leaf life span was estimated to be 25.5, 28.3 and c.24.8 days, respectively, in 1986, 1987 and 1988 (see Table 2). Since the respective vegetation periods were 154, 177 and c.155 days, the turnover of leaves (length of the vegetation period 

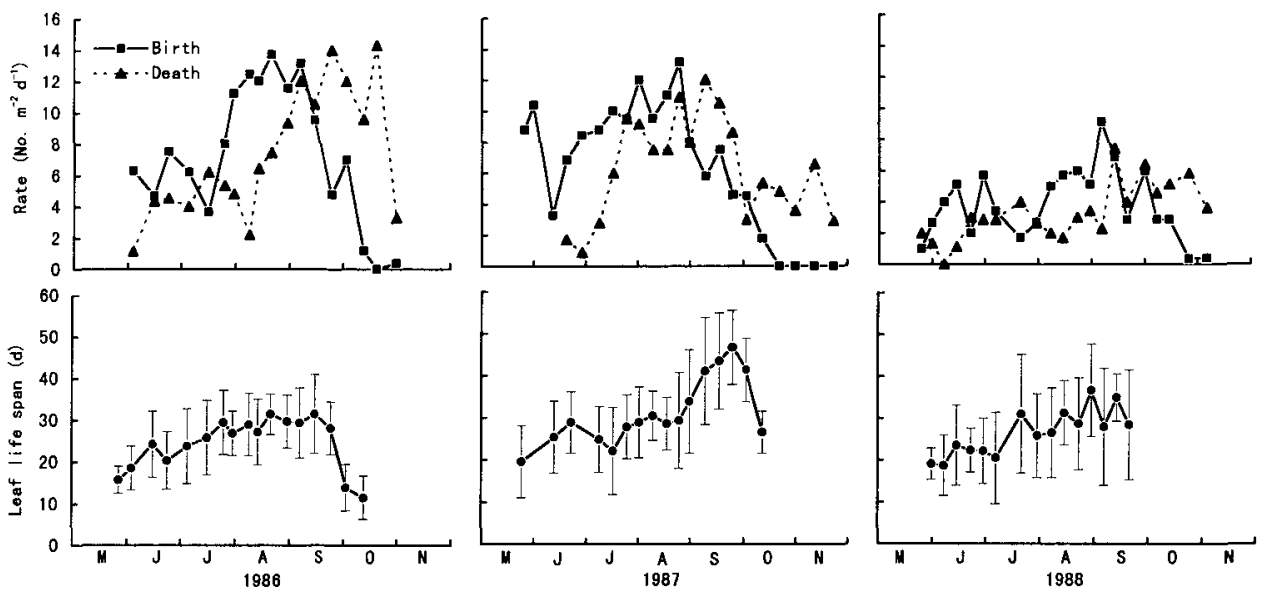

Fig. 2 Temporal changes in mean birth/death rates and leaf life span of $B$. schreberi from 1986 to 1988 . Vertical bars show SD.

divided by mean leaf life span) can thus be calculated as $6.04,6.26$ and c. 6.25 .

Figure 3 shows the seasonal and annual changes in leaf area index (LAI) and leaf mass. Linear regression equations shown in Table 1 were used to estimate the leaf area and leaf dry weight. The seasonal maximum LAI (and thus leaf mass) occurred during late August in 1986 and 1987 and early September in 1988. There was only a slight difference between the actual and the potential biomass in each year. In general, the proportion of damaged areas mostly caused by the grazing of a herbivorous insect (Galerucella nipponensis LABOISSIERE) was relatively high (10-30\%) before
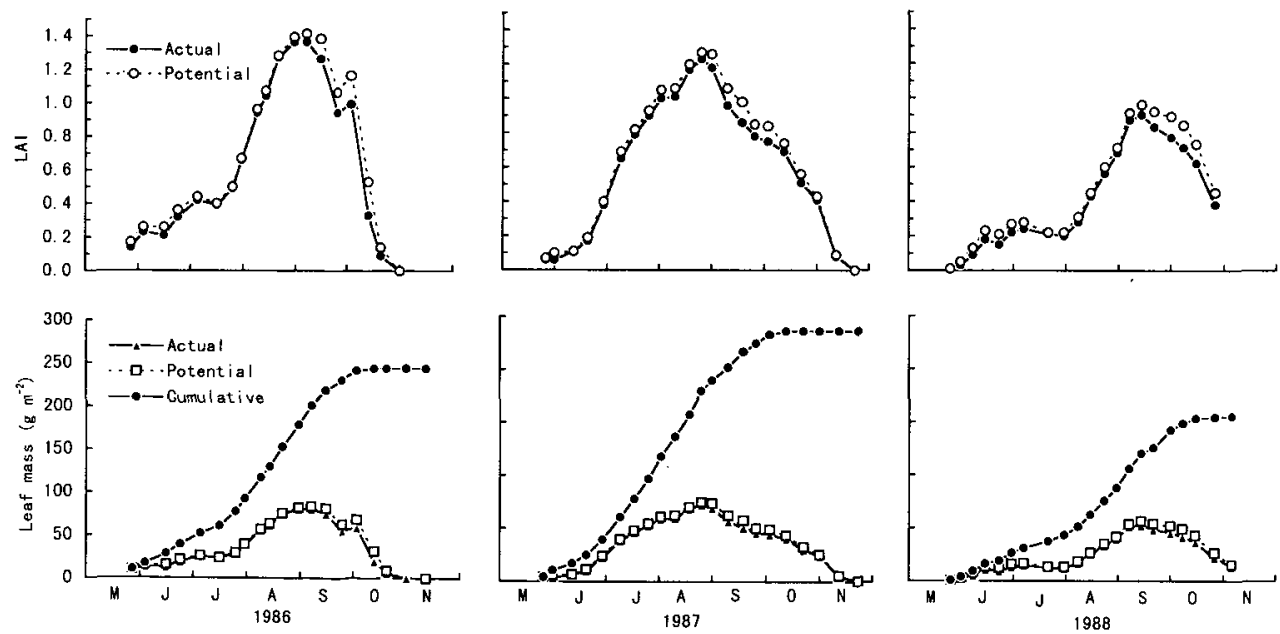

Fig. 3 Temporal changes in LAI and biomass of B. schreberi from 1986 to 1988. The difference between the actual and potential lines represents damaged and/or missing amounts at each date. 
Table 1. Linear regression equations of each leaf blade characteristic of Brasenia schreberi $(n=233)$.

$$
\begin{aligned}
& A=0.767 \times L \times W+0.386\left(r^{2}=0.989\right) \\
& A=7.751 \times L-29.734\left(r^{2}=0.959\right) \\
& A=13.910 \times W-37.817\left(r^{2}=0.933\right) \\
& D W=4.308 \times L \times W+12.924\left(r^{2}=0.652\right) \\
& D W=5.678 \times A+8.425\left(r^{2}=0.673\right)
\end{aligned}
$$

$A$, Area $\left(\mathrm{cm}^{2}\right) ; D W$, dry weight $(\mathrm{mg}) ; L$, Length $(\mathrm{cm}) ; W$, Width $(\mathrm{cm})$. In case when either width or length was unable to measure because of severe damage and / or decay, second or third equation was used to estimate leaf area.

Table 2. Summary of turnover and production data for floating leaves of Brasenia schreberi in 1986, 1987 and 1988.

\begin{tabular}{lrrr}
\hline Parameter & 1986 & 1987 & \multicolumn{1}{c}{1988} \\
\hline Annual mean life span (d) & 25.5 & 28.3 & $\mathrm{c} .24 .8$ \\
Turnover $\left(\mathrm{d} \mathrm{d} \mathrm{d}^{-1}\right)$ & 6.04 & 6.26 & $\mathrm{c} .6 .25$ \\
Maximum LAI $\left(\mathrm{m}^{2} \mathrm{~m}^{-2}\right)$ & 1.36 & 1.23 & 0.9 \\
Maximum leaf mass $\left(\mathrm{g}\right.$ dry weight $\left.\mathrm{m}^{-2}\right)$ & 80.5 & 72.6 & 52.5 \\
Annual net production $\left(\mathrm{g}\right.$ dry weight $\left.\mathrm{m}^{-2} \mathrm{yr}^{-1}\right)$ & 243.5 & 236.3 & 154.9 \\
$\mathrm{P} / \mathrm{B}_{\max }\left(\mathrm{yr}^{-1}\right)$ & 3.03 & 3.25 & 2.95 \\
\hline
\end{tabular}

early summer when there was a small leaf mass, but it declined $(<10 \%)$ around August when there was a large leaf mass. Annual net production, which is expressed by the cumulative potential dry weight of new borne leaves, showed a marked difference among the years.

The turnover and production data are summarized in Table 2. Most of these parameters are similar to those of other floating-leaved aquatic macrophytes (TsuchiYa, 1991; KunII and ARAMAKI, 1992). While such parameters as annual mean life span, turnover of leaves and the annual net production to seasonal maximum biomass ratio $\left(\mathrm{P} / \mathrm{B}_{\max }\right.$ ratio) were relatively stable for three years, maximum LAI, maximum leaf mass and annual net production showed year-to-year differences. TsuchIYA (1989) reported that under different nutrient levels the biomass turnover of Hydrocharis dubia $\mathrm{L}$. was little affected by nutrient concentration, whereas maximum biomass and net production differed markedly depending on the nutrient level. KoK et al. (1990) also reported that the mean life span and the turnover rates of floating leaves in Nuphar lutea (L.) SM. and Nymphaea alba L. were little affected by environmental factors in the various systems. It is probable that both turnover and leaf life span are under control of the plant rather than environmentally influenced (КоK et al., 1990), although it is still not clear which mechanisms cause the mean leaf age and the turnover to remain so constant (but see REICH et al., 1992). 
Figure 4 shows the relationship between environmental variables (cumulative sunshine duration and cumulative temperature) and net production and leaf mass. The cumulative value used here denotes the sum total of the values averaged at 10-day intervals for 150 days from 1 May to late September during which the plant showed good growth. The cumulative sunshine duration had a significant relation to both net production $(P<0.05)$ and maximum biomass $(P<0.005)$. However, the cumulative temperature was related neither to net production nor leaf mass. This result confirms that sunshine duration during the growing season is crucial for the leaf production of $B$. schreberi. The importance of sunshine duration for plant growth has been well described in the field of agriculture and/or horticulture. More attention should be paid to the influence of sunshine duration on the growth of floating leaved plants other than $B$. schreberi. The possibility of the influence of temperature on leaf production can not be denied in view of the present result since the difference in cumulative temperature among the years is thought to be too small (maximum $332.5^{\circ} \mathrm{C}$ in 1987 and minimum $327.1^{\circ} \mathrm{C}$ in 1986) to detect the response of temperature to a change in leaf production (see TsuchiYa et al. (1987) for the relation between spring temperature and summer biomass of Trapa natans L.).
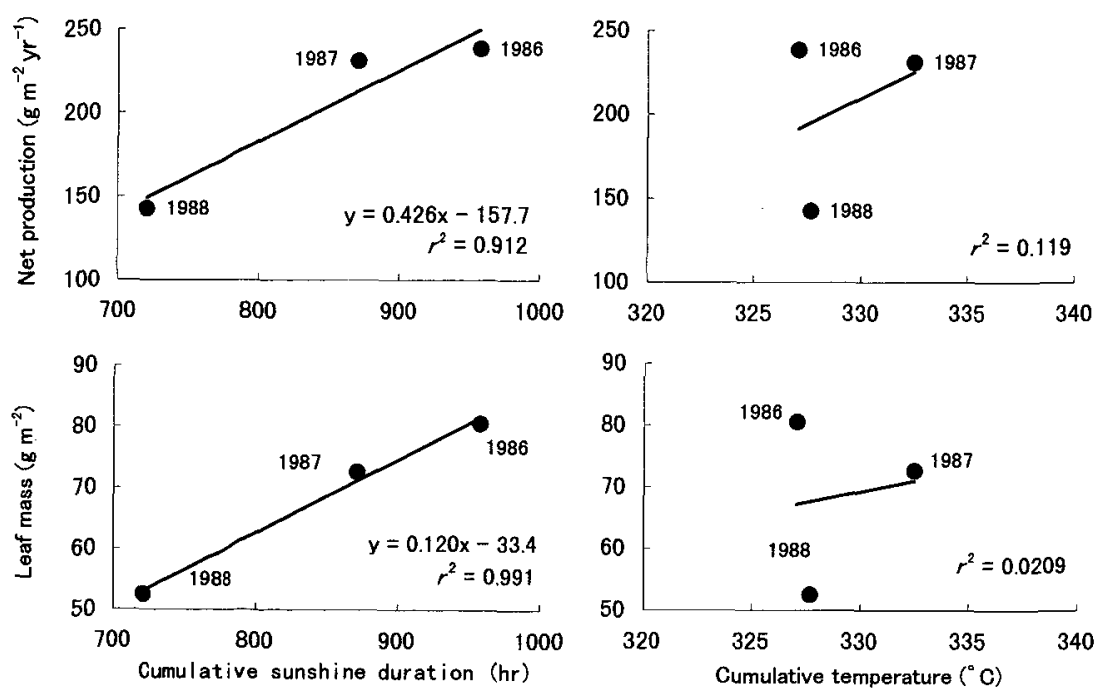

Fig. 4 Relationship between environmental variables (cumulative sunshine duration and cumulative temperature) and net production and leaf mass of $B$. schreberi. The cumulative denotes the sum total of the values averaged at 10-day intervals for 150 days from 1 May to late September in each year. The values of net production used here are those obtained in late September of each year.

In summary, values such as annual mean life span, leaf turnover rate, LAI, seasonal maximum leaf mass, net production and $\mathrm{P} / \mathrm{B}_{\max }$ ratio of $B$. 
schreberi were similar to those of other floating-leaved aquatic macrophytes, despite the fact that LAI, seasonal maximum leaf mass, and net production changed considerably among the years. Leaf mass production showed year-to-year changes depending on the difference in cumulative sunshine duration. It is thus confirmed that sunshine duration during the growing season is very important for the leaf production of $B$. schreberi.

\section{ACKNOWLEDGMENTS}

This paper is dedicated to Professor Emeritus Isao IKUsHIMA of Chiba University, in honor of his fruitful career in the ecology of aquatic macrophytes. The author is much obliged to Mr. M. Aramaki, Mr. N. Katsube and Mr. T. YAMAZAKI for doing the hard work in the field.

\section{REFERENCES}

Adams, F. S. (1969) : Winterbud production and function in Brasenia schreberi. Rhodora, $71: 417-433$.

Chrysler, M. A. (1938) : The winter buds of Brasenia. Bull.Torrey Club, 65 : 277-283.

Den HaRToG, C. and G. van der VELDE (1988) : Structural aspects of aquatic plant communities. In Vegetation of Inland Waters, J. J. Symoens (ed.) : 113153. Kluwer, Dordrecht.

Elakovich, S. D. and J. W. Wooten (1987) : An examination of the phytotoxicity of the water shield, Brasenia schreberi. J. Chem. Ecol., 13 : 1935-1940.

Hara, H., T. Matsuda and T. Matsuda (1988) : Effects of shading, shallowing and aeration on the growth and crop biomass of Brasenia schreberi. Scientific Report of the Faculty of Agriculture, Ibaraki University, 36:29-36 (in Japanese) .

Hutchinson, G. E. (1975) : A Treatise on Limnology III. Limnological Botany. Wiley, New York.

ITo, M. (1986) : Studies in the floral morphology and anatomy of Nymphaeales. III. Floral anatomy of Brasenia schreberi Gmel. and Cabomba caroliniana A. Gray. Bot. Mag. Tokyo, 99 : 169-184.

Iто, M. (1987) : Phylogenetic systematics of the Nymphaeales. Bot. Mag. Tokyo, $100: 17-35$.

KaUL, R. B. (1976) : Anatomical observations on floating leaves. Aquat. Bot., 2 : $215^{-234 .}$

Khanna, P. (1965) : Morphological and embryological studies in Nymphaeaceae II. Brasenia schreberi Gmel. and Nelumbo nucifera GaERTN. Aust. J. Bot., $13: 379-387$.

KoK, C. J., G. van der Velde and K. M. Landsbergen (1990) : Production, nutrient dynamics and initial decomposition of floating leaves of Nymphaea alba L. and Nuphar lutea (L.) SM. (Nymphaeaceae) in alkaline and acid waters. Biogeochemistry, $11: 235-250$.

KUNII, H. (1993) : Rhizome longevity in two floating-leaved aquatic macrophytes, Nymphaea tetragona and Brasenia schreberi. J. Aquat. Plant Manage., 31 : 94-98. 
Kuni, H. and M.Aramaki (1987) : Preliminary report on the dynamics of floating leaves in Nymphaea tetragona and Brasenia schreberi. Bull.Water Plant Soc. Jpn., $29: 24-26$ (in Japanese).

Kunit, H. and M. AramaKi (1992) : Annual net production and life span of floating leaves in Nymphaea tetragona GEORGI : a comparison with other floatingleaved macrophytes. Hydrobiologia, 242 : 185-193.

Kuni, H. and R. TsubaKi (1987) : Aquatic plants and seasonal changes of water quality in Pond Engi-ike, Shimane Prefecture. Studies in San'in Region (Natural Environment), 3: 7-12 (in Japanese with English abstract).

MATsuda, T. and H. HaRA (1985) : On the problems related to the cultivation of water-shield (Brasenia schreberi J. F. GMEL.) at the reclaimed land of Haga swamp. Scientific Report of the Faculty of Agriculture, Ibaraki University, 33 : 1-13 (in Japanese with English summary).

Raymond, M. and P. Dansereau (1953): The geographical distribution of the bipolar Nymphaeaceae, Nymphaea tetragona and Brasenia schreberi. Proc. Pacific Sci. Congr., $7(5)$ : 122-131.

Reich, P. B., M. B. Walters and D. S. Ellsworth (1992) : Leaf life-span in relation to leaf, plant, and stand characteristics among diverse ecosystems. Ecol. Monogr., 62 : 365-392.

TozAKI, T. (1982) : Distribution of Brasenia schreberi and water conditions. Journal of Japanese Society of Irrigation, Drainage and Reclamation Engineering, $50(6): 481-485$ (in Japanese).

TozAKI, T. (1984): Seasonal stem elongation and growth curve of Brasenia schreberi. Journal of Japanese Society of Irrigation, Drainage and Reclamation Engineering, 52(2) : 121-127 (in Japanese).

TozAKI, T. (1985) : Stem elongation of Brasenia schreberi and water depth. Journal of Japanese Society of Irrigation, Drainage and Reclamation Engineering, 53(6): 523-527 (in Japanese).

Tsuchiya, T. (1989) : Growth and biomass turnover of Hydrocharis dubia culturted under different nutrient conditions. Ecol. Res., 4: 157-166.

TsuchiYA, T. (1991) : Leaf life span of floating-leaved plants. Vegetatio, 97 : 149- 160.

Tsuchiya, T., S. Nohara and H. IwaKi (1987) : Annual and seasonal variations in biomass of a floating-leaved plant, Trapa natans L., in Takahamairi Bay of Lake Kasumigaura, Japan. Jpn. J. Limnol., 48 : S39-S44.

Van der Velde, G. and P. M. M. Peelen-Bexkens (1983) : Production and biomass of floating leaves of three species of Nymphaeaceae in two Dutch waters. Proc. Int. Symp. Aquat. Macrophytes, Nijmegen : 230-235. Faculty of Science, Department of Aquatic Ecology, Nijmegen, The Netherlands.

Hidenobu KUNII : Research Center for Coastal Lagoon Environments, Shimane University, Matsue 690-8504 (國井秀伸：干 690-8504 松江市西川津町 1060 , 鳥根大学汽水域研究センター)

(Received : 7 June 1999 ; Accepted : 13 July 1999) 


\title{
ジュンサイの浮葉の純生産, 現存量および 寿命の年変動と季節変動
}

\author{
國井秀伸
}

摘要

島根県松江市のため池において, 浮葉植物ジュンサイの浮葉の寿命, 葉面積および現存 量を，非破壊的なマーキング法によって 1986 年から 1988 年にかけて定量的に钼察した。 この 3 年の間で, 浮葉の葉面積指数，現存量および純生産量は，それぞれ $0.9 \sim 1.36,52.5$ ～80.5 g 乾重 $\mathrm{m}^{-2}$ および 154.9 243.5 $\mathrm{g}$ 乾重 $\mathrm{m}^{-2}$ 年-1 と大きく变動した。しかしながら， 年平均寿命, 回転率および $\mathrm{P} / \mathrm{B}_{\max }$ 比は，それぞれ 25 28 日，6.0 6.3 および 2.95 3.25 年 ${ }^{-1}$, 比較的一定の値を示した。浮葉の純生産量 $(P<0.05)$ と現存量 $(P<0.005)$ は, 5 月から 9 月にかけての積算日照時間と有意な直線関係にあったが, 気温の積算值との有 意な関係は見られなかった。今回の結果はジュンサイの成長にとって日照時間が非常に重 要であることを示唆している。 